\title{
Embracing the Instagram Waves - The New Business Episode to the Potential Entrepreneurs
}

\author{
Noor Azuan Hashim, Ph.D. \\ School of Management \\ Faculty Economics and Management \\ Universiti Kebangsaan Malaysia \\ 43600 UKM Bangi, Selangor \\ Malaysia \\ E-mail: azuan@ukm.edu.my
}

Received: October 31, 2017

Accepted: October 5, 2017 Published: December 20, 2017

doi:10.5296/jebi.v4i2.12092

URL: http://dx.doi.org/10.5296/jebi.v4i2.12092

\begin{abstract}
Instagram, one of the social media applications on smart phone is gaining popularity as a mode of social interaction recently. Many people, especially young people, have used this application, not only for daily communication and sharing, but also for buying and selling products. Because of the heavy usage of Instagram, there is substantial interest in making this medium a commercial site, particularly among entrepreneurs who want to explore the potential of their businesses. However, little is understood from empirical viewpoint about the intensity of Instagram usages and its impact on society. This study seeks to investigate the perceived impact of Instagram on Malaysian potential entrepreneurs. A survey was administered which involved 115 individual. The findings revealed that most respondents in this study believed that Instagram is the future way of doing their businesses. In fact, they believed that those who want to be entrepreneurs need to have Instagram as they would not only allow them to share their products and services with other people but also assist them to make vital and critical business decisions. In addition to this finding, some other issues on the Instagram application were also revealed in this paper.
\end{abstract}

Keywords: Social media, Instagram, Entrepreneurs, Impact, Business, Malaysia

\section{Introduction}

Whether we realize it or not, the advances of technology, particularly the Internet, has changed not only the way we live and think, but also the way we purchase products, 
communicate, travel, the way we learn and many others changes that have been brought about by these continuous technological advancements (Davis et al., 2014). It has made the world change faster and wilder. It is evolving at a very fast rate, and what most people did not even think could be real a few years ago, is now becoming a reality. It seems so hard to escape the presence of technology in today's world. People are becoming more and more dependent on technology. In fact, many people praise the technological gadgets that they use in their everyday lives, and many of us depend on it to get us through the day, to do our job, to get around, and to find certain things (Kaplan \& Haenlein, 2010).

Social media, one of the Internet applications, has evolved drastically especially with the advancement of information technology via the Internet. It has transformed the way human interacts and expanded the boundary of communication in terms of contents and contexts. With the growth of social media, its influence is also expanded beyond personal communication, and its impact can be obviously seen in the way business operates (Keenan \& Shiri, 2009). Since the advent of social media, many studies have explored its effects on the whole spectrum of human interaction and more are moving towards exploring its impact on business (e.g. Valos et al., 2014; Fischer \& Reuber, 2011). Although studies on social media in business development is still limited (Michaelidou et al., 2011), many have suggested that social media provides the fastest platform to start and build a business for budding entrepreneurs.

Instagram, an application of social media, is one of the changes in communication technology that is commonly used on smart phones has become a wide spread application nowadays especially among young people. It is a mobile, desktop, and Internet-based photo-sharing and service that allows users to share pictures and videos to individuals or groups of friends either publicly or privately at no cost as long as their phones are connected to the internet (Jenkins, 2015). This application is also highly addictive and could create a great impact on regular users. According to Thamwita and Backman (2013), application such as Instagram can leave a trace that becomes difficult to control and cure. Part of the reason is because it displays pictures and videos which much easier and faster to capture people brain to remember (Davis et al., 2014) and the tendency to watch it again is huge. Although there is quite a number of a research on Internet and social media, little is understood about how and why people have adopted this particular application, Instagram.

Thus, the goal of this study is to provide a deeper understanding of the motives and perceptions of Instagram and also to explore the impact of this application in the society, especially among potential entrepreneurs. This paper is organized as follows: the introduction of the paper follows by the literature review, the conceptual framework of this study, the methodology of the study, and findings and discussion of the study. Finally, the last section displays the concluding remarks and implications of the study. 


\section{Literature Review}

\subsection{Social Media}

The growth of social media web sites has increased the channels of communication in intra and inter-organisations (Kirschner, and Karpinski, 2010). Within organization, social media has improved collaboration between team members in an organization that lead to a better outcome (Valos et. al, 2011). It also allows people to progressively create and share ideas, and expand thoughts and innovativeness. Essentially, social media provides venue to increase personal and organizational gains, and it is unfortunate if this opportunity is not being leveraged by business organisations. Social interaction plays a significant role in effectuation process (Fischer and Reuber, 2011), and understanding of this in the context of entrepreneurship is important to understand the implications of social media in enterprise growth and sustainability.

It is undeniable that social media plays an important role in impacting our culture, our economy and our overall view of the world. Social media is a new forum that brings people to exchange idea, connect with, relate to, and mobilize for a cause, seek advice, and offer guidance (Moran et al., 2011; Kirschner, and Karpinski, 2010). Social media has removed communication barriers and created decentralized communication channel and open the door for all to have a voice and participate in a democratic fashion including people in repressive countries (Amedie, 2015). This media outlet accommodates a wide variety spontaneous, formal, informal, scholarly and unscholarly writings to flourish. Since the raising of social media, there is some changes on people's life styles. It started from the technology and idea of socializing through the internet and from a chat based media application in the computer; it is now evolve into a new dimension, a social network (Abbott et al., 2014; Davis et al., 2014).

In 2004, the most popular social media, Facebook was introduced by Mark Zuckerberg. Facebook then had 30 million of registered users in 2007, making it the biggest social-networking site with focus on education (Boyd and Ellison, 2007), and later on in other areas. After Facebook, there is a lot of other application social media been created and some are just not popular as its functions may just an imitation to Facebook. Some those are quite known such as Friendster, Line, and Kakao Talk. Twitter, on the other hand, introduced a different platform for those who wanted to share just text update quickly within limited networks. Later in 2010, a social media with the idea of photo sharing called Instagram was introduced. It features on the spot editing of the photos to share and upgraded to share videos as well (Kuppuswamy and Narayan, 2010). YouTube is also part of it where people share thousands kind of videos and it is used together with other social applications for a longer length of videos (Keenan and Shiri, 2009).

All these social media applications have built an online community where it provides space for people to communicate. People share their thoughts, activities, friends and families update, events, photos and videos. Smartphone makes life easier when all the applications are made available inside the system and anyone with access to Internet could update just about anything, anywhere at any time. Anyone nowadays seems 'compulsory' to have an account with the 
social media applications. Millions have registered and in 2013, and according to Etherington (2013), it has 100 million monthly active users, and 40 million photos were uploaded per day, with more than 8,500 likes and 1,000 comments gained per second.

Photo sharing is not new. Polaroid was a game changer where it enables taking photos and shared within minutes (Dailymail, 2017). It then evolved to what we call digital photography. New trends are emerging due to the popularity of photo sharing practices. Images of any footage can be taken by personal devices and are commonly in news reports. It also makes a phenomenon trends called 'Selfie' - a self-portrait photograph, typically taken with a digital camera or camera phone held in the hand or supported by a selfie stick (Oxford Dictionary, 2017). The intersection of smartphones and social networking sites has taken photography to a new playing field, as demonstrated by the success of Instagram.

Throughout the years, people from business areas seems to see the opportunities gained through social media to interact with potential customers. Social networking sites have become a hot issue for marketers (Zarrella, 2009; Paquette, 2013). Social network marketing has included both the traditional and the non-traditional sense of marketing strategy (Cowden, 2014). The communities in the social networking are the largest and a very good market. Many companies are now commonly using social media to promote their brands and to maintain a friendly relationship with their customers (Saravanakumar \& Lakshmi, 2012). Either using Facebook of Instagram, users are actually updating both applications since Facebook has bought Instagram for one billion dollars in 2012 (The New York Times, 2012). This helps marketers to attract customers from both channels at the same time.

\subsection{Instagram}

Instagram is simply an online social networking service, mobile photo and video sharing application that allows people to take pictures and videos, and share them on the mobile platform of Internet. As of late last year, it continues to gain popularity with over 300 million registered users (Asehinde, 2015). It is a rapidly growing photo and video sharing platform with more than 16 billion photos uploaded and shared (Cleary, 2014). The uses of Instagram are unlimited, free and simple.

Instagram, like any other social networks is based around having friends or followers. The social strategy was not just limited to existing social networks for sharing but also to build and connect its own network (Abbott et al., 2014). It is a platform which helps to connect a user with other users from different part of the world via Instagram Direct. In fact, it can strengthen the user relationship with current followers, while giving opportunities for them to meet new friends, fans, and influencers (Jenkins, 2015).

\subsection{Instagram and Marketing}

Apart from being a platform for social networking services, Instagram can be a powerful and useful business tool called Instagram marketing. Instagram marketing as an individual or as a brand, may create multiple opportunities for many marketers. According to Asehinde (2015), Instagram serves as a social media marketing tool to build and gain brand recognition by helping them to reach out for new customers and promote their products or services. Instagram 
can boost engagement 15 times more than Facebook, Twitter or Google+ (Jenkins, 2015). The Instagram posts can be seen or discovered by more people. For example, by including the appropriate or audience-specific hashtags in the updates, the marketers can easily and effectively reach new people interested in their products as well as to reach the target audience. The hashtags not only describe the photos and business, but are also actively searched for and used on Instagram (Jenkins, 2015). The marketers can share information at the same time with their customers and business partners. Doing marketing on the Instagram platform may help the marketers in many ways such as to establish their presence, encourage follower engagement and run contests.

Instagram provides the audience with unique visual content while encouraging community engagement. Instagram's video feature allows the marketers to create visually short compelling stories and promote or advertise their brand and marketing message online. They may create a video look-book for potential customers to browse through. Combine these features with the fact that it offers ease of sharing on other social networking platforms lead to more ease to promote marketing. Moreover, the marketers can also get customer feedback through Instagram Direct. The marketers can create deeper connections with their current and potential customers apart from being visible in the social network.

\section{Conceptual Framework}

Instagram application is considered an innovative advancement in communication technology (Shamare, 2014). In order to find a suitable framework for this study, a list of technological diffusion literature was reviewed. Among them are Roger's (1995) diffusion of innovation theory (DOI), Davis's (1989) technology acceptance model (TAM), Tornatzky and Fleischer's (1990) technological-organisational-environmental model (TOE), and Azjen's (1991) theory of planned behaviour (TPB). Both DOI and TOE are mostly used in the study of innovation diffusion in organisation. TAM and TPB models focus mainly on user acceptance to analyse automation processes in the early phases of IT diffusion (Ordanini, 2006), which is the most appropriate model for this study.

TAM model has been used by many researchers to study user acceptance and it is an extension of TPB model. The model suggests that when users are presented with a new technology, a number of factors influence their decision about how and when they will use it, notably: 1) perceived usefulness (PU) - "the degree to which a person believes that using a particular system would enhance his or her job performance"; and 2) perceived ease-of-use (PEU) - "the degree to which a person believes that using a particular system would be free from effort" (Davis, 1989). TAM has been used vigorously in ICT studies and has been adopted and adapted by many researchers. The two variables mentioned earlier will be considered in this study to understand individuals' perception on Instagram application. 15 questions were adapted and designed to illustrate the PU and PEU. 


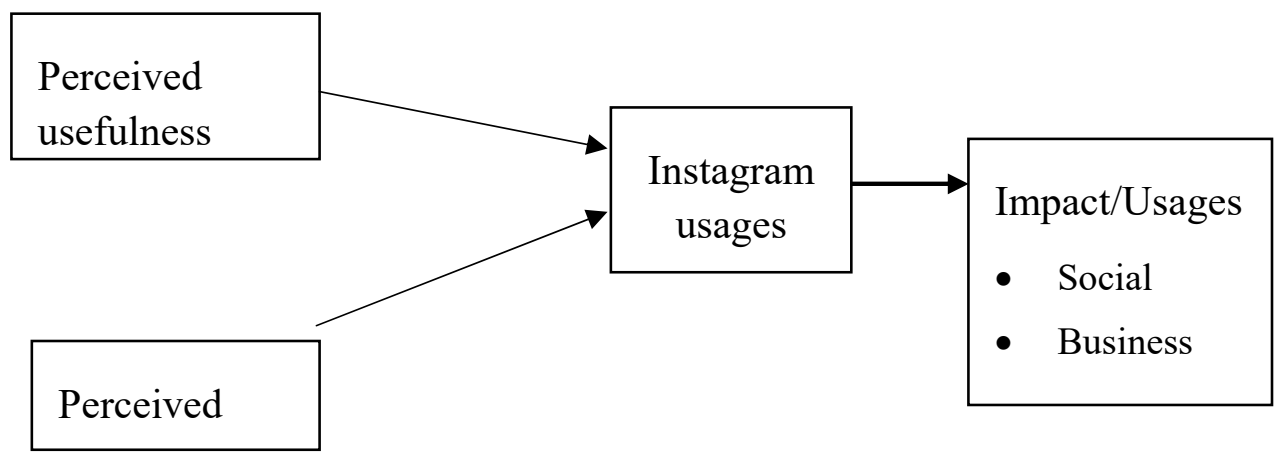

Figure 1. Conceptual framework of the study

The framework in Fig. 1 is used in this study to investigate the usages and impact of Instagram among potential entrepreneurs. The research questions are: 1) to what extent have potential entrepreneurs use Instagram application; and 2) to what extent have the Instagram usages among impact these potential entrepreneurs.

\section{Research Methodology}

\subsection{Research Method}

The data for this paper is gathered through a questionnaire survey - a data gathering method to collect, analyse and interpret the views of a group of people from a target population (Baškarada, 2014; Gratton and Jones, 2004; Leedy and Omrod, 2005). Surveys have been used in various fields of research, such as sociology, marketing research, politics and psychology (Hashim, 2011; Leedy and Omrod, 2005). Some advantages of survey include the relatively easy to administer, can be conducted remotely which can reduce or prevent geographical dependence, capability of collecting data from a large number of respondents and also can be administered remotely via online, mobile devices, mail, email, kiosk, or telephone (Sekaran, 2016).

For the purpose of this study, electronic questionnaire survey has been carried-out. Part of the reason is because this study embarked on large number of respondents who used online application and it is the most cost effective. An online survey development cloud-based software, SurveyMonkey was used in this study. SurveyMonkey is a free or paid software (depending on the usage) that can be used to design questionnaire for online survey. Through a link that provided by this software, respondents can reach and answer the online survey provided they have access to the internet from various platforms such as email, website, and even in the Facebook (Nagalakshmi and Treved, 2015). Data update from respondents can be seen live and results are processed automatically by the application (Harrsion, 2016). Although a subscription is required to use the system, the payment was just at minimal cost. Many researchers have started using this software to gather data from wide geographical survey (Nagalakhmi and Trevedi, 2015; Harrison, 2016). 


\section{Macrothink}

\subsection{Sampling}

A sample is a subset of the population where it comprises some members selected from it. Sampling begins by defining the target population. The restriction such as geographical boundaries and time constraints should be considered. This research defined the target population before making its' sampling design. Convenience sampling, one of the nonprobability sampling, was employed where the elements in the population do not have any probabilities attached to their being chosen as subjects (Sekaran, 2016). It refers to the collection of information from members of the population who are conveniently available to provide it. In this case, respondents were chosen from the author's business contact list of Facebook and email. Over 300 emails have been sent with the survey link and at least a daily posting on Facebook wall were done. As a result, this research received 115 respondents who have responded to the online survey.

\section{Findings and Discussions}

Four parts were developed in the questionnaire for data collection. All the data were analyzed using the Excel and also Statistical Packages for the Social Science (SPSS) software.

\subsection{Respondent Profile}

As mentioned earlier, 115 respondents have posted their answers on the SurveyMonkey platform. All respondents have at least used one of the social media applications and have accessed this media through either computers or mobile phones. Most of the respondents used smart phones and most of them were using IPhone, Samsung or Blackberry. Only one respondent stated no usage of smart phone. Some of the respondents have more than one phone and some of them have a dedicated phone for social networking activities on Instagram. Many respondents were between 21 to 30 years old (68\%), and half of them are professional worker. There were more female respondents compared to male. Table 1 displays the respondent characteristics.

Table 1. Respondents' characteristics ( $\mathrm{n}=115)$

\begin{tabular}{|c|c|c|c|}
\hline Age & & Type & $o f$ \\
\hline Below 20 & $1 \%$ & Employment & \\
\hline $21-30$ & $68 \%$ & Professional & $50 \%$ \\
\hline $31-40$ & $26 \%$ & Non-professional & $30 \%$ \\
\hline Above 40 & $5 \%$ & Self employed & $9 \%$ \\
\hline Gender & & Student & $18 \%$ \\
\hline Male & $24 \%$ & Monthly & \\
\hline
\end{tabular}




\begin{tabular}{llll}
\hline Female & $76 \%$ & \multicolumn{2}{l}{ household income } \\
& & Less RM1000 & $8 \%$ \\
& & RM1000-RM2000 & $13 \%$ \\
Ethnicity & & RM2001-RM3000 & $25 \%$ \\
Chinese & $3 \%$ & RM3001-RM5000 & $32 \%$ \\
Malay & $95 \%$ & More & than \\
Indian and others & $2 \%$ & RM5000 & \\
& & &
\end{tabular}

There are at least two important distributions in this respondent profile - age and gender. It is found that most respondents aged between 21 and 30 years old, which means the respondents were consider young, maybe they are students or at the earlier stage of their job experience. Another important variable is gender, which shows that $76 \%$ of the respondents were women, which we may speculate that woman are fonder to answer questionnaires compared to man. In terms of type of employment, $50 \%$ of the respondents were professional workers, while $30 \%$ were non-professional and the remaining $20 \%$ were self-employed or student. More than $50 \%$ respondents have income between RM2000 and RM5000.

\subsection{Level of Awareness}

All respondents knew about Instagram. However, out of 115 respondents, $71 \%$ stated that they have a registered Instagram account, while the rest has yet to register an account. Although without a proper register Instagram account, these respondents stated they knew some sort about Instagram, however, they are yet to explore its potential. One possible reason maybe some of them were satisfied with the used of other social networking sites such as Facebook and Twitter. They might not need Instagram as they can also network and watch pictures and videos through other sites.

Table 2 shows reasons why the respondents have Instagram account.

\begin{tabular}{lllllll}
\hline & $\mathrm{n}=115$ & & Male, $\mathrm{n}=28$ & \multicolumn{2}{c}{ Female, $\mathrm{n}=87$} \\
Why Join Instagram & Frequency & $\%$ & Frequency & $\%$ & Frequency & $\%$ \\
\hline Do not have Instagram & 33 & $28.7 \%$ & 18 & $64.3 \%$ & 15 & $17.2 \%$ \\
Social Relation/Networking & 30 & $26.1 \%$ & 5 & $17.9 \%$ & 25 & $28.7 \%$ \\
Browsing Pictures/Images & 16 & $13.9 \%$ & 0 & $0.0 \%$ & 16 & $18.4 \%$ \\
Online Shopping & 16 & $13.9 \%$ & 0 & $0.0 \%$ & 16 & $18.4 \%$ \\
Business Purposes & 10 & $8.7 \%$ & 2 & $7.1 \%$ & 8 & $9.2 \%$ \\
\hline
\end{tabular}


Displaying products

Others

Table 2. Why Join Instagram $(\mathrm{n}=115)$

Most of the respondents (more than 25\%) created Instagram account because of social relation, i.e. to socialize with their friends or to build new relationship, follows by browsing pictures and images (13.9\%). Almost 30\% of the respondents use Instagram for commercial purposes such as online shopping, business purposes and displaying products which means there is a potential of business transaction through Instagram. Others stated they use Instagram for some other purposes such as for relaxing and entertainment.

As expected, there is more female using Instagram in this study, almost seven times than the male. Other study (for example, Hashim (2016)) also found a similar finding, i.e. more female used Instagram than their counterpart. In fact, statistics by Statistica (2017) also reveals that female Instagram users dominate the trend. This could explain the fact that women love pictures on the Instagram and also loves online window shopping as 'retail theraphy' (Kacen, 1998; Hashim et al., 2016).

Those who have a registered account $(\mathrm{N}=82)$ stated that their frequency of usages as below (Table 3).

Table 3. Frequency usages $(n=82)$

\begin{tabular}{lll}
\hline Frequency Users Usage & Frequency & Percentage \\
\hline Once a month & 10 & 12 \\
Once a week & 13 & $15 \%$ \\
2-3 times per day & 35 & $43 \%$ \\
$2-3$ times per hour & 7 & $9 \%$ \\
Very often & 17 & $21 \%$ \\
\hline
\end{tabular}

More than $70 \%$ of respondents access their Instagram account more than one time per day, which can be considered they are active Instagram users. Surprisingly, more than half of the respondent who are active users of Instagram claim that they browse Instagram at night (see Table 4) and more than 30\% respondent state that the best time for browsing Instagram is after $11.00 \mathrm{pm}$. Possible reasons could be at this hour internet line is much faster because less people is people connected to the internet - most has already gone to bed. For married couple 


\section{IIMacrothink}

with children, particularly for a woman, this is the best time because usually at this time all their children has gone to bed and the house chores have been settled. This can be shown in the analysis that most respondents, particularly the women, agreed that the best time on Instagram is after $11 \mathrm{pm}$.

Table 4. Time browsing Instagram

\begin{tabular}{lllll}
\hline \multirow{2}{*}{ Why Join Instagram } & \multicolumn{2}{l}{ Male, $\mathrm{n}=10$} & \multicolumn{2}{l}{ Female, $\mathrm{n}=72$} \\
& Frequency & $\%$ & Frequency & $\%$ \\
\hline Day & 2 & $20.0 \%$ & 15 & $20.8 \%$ \\
Night & 5 & $50.0 \%$ & 25 & $34.7 \%$ \\
Day and Night & 3 & $30.0 \%$ & 16 & $22.2 \%$ \\
\hline
\end{tabular}

\subsection{Utilization of Instagram}

In order to understand the usages of Instagram, a list of potential activities of Instagram have been displayed in the questionnaire.

Table 5 shows the mean of factors that leads to the usages of Instagram in the survey.

Table 5. Mean Comparison of Utilization of Instagram

\begin{tabular}{lccccc}
\hline & $\mathrm{N}$ & Min & Max & Mean & Std. Dev \\
\hline $\begin{array}{l}\text { To_promote_products_brands (PU) } \\
\text { Engagement_with customers (PU) }\end{array}$ & 82 & 0 & 5 & 3.78 & 1.468 \\
$\begin{array}{l}\text { Strategy_and_Marketing_Tools } \\
\text { (PU) }\end{array}$ & 82 & 0 & 5 & 3.67 & 1.515 \\
$\begin{array}{l}\text { People_share_find_informations } \\
\text { (PEU) }\end{array}$ & 82 & 0 & 5 & 3.61 & 1.375 \\
$\begin{array}{l}\text { Most_used (PEU) } \\
\text { Hashtag_helps (PU) }\end{array}$ & 82 & 0 & 5 & 3.55 & 1.425 \\
$\begin{array}{l}\text { Useful_online_shopping (PU) } \\
\text { Online_album (PEU) }\end{array}$ & 82 & 0 & 5 & 3.51 & 1.501 \\
\hline
\end{tabular}




$\begin{array}{lccccc}\text { Update_celebrities_life (PEU) } & 82 & 0 & 5 & 3.29 & 1.517 \\ \text { Powerful_than_other_apps (PU) } & 82 & 0 & 5 & 3.09 & 1.405 \\ \text { Share_my_photos_videos (PEU) } & 82 & 0 & 5 & 3.06 & 1.798 \\ \text { Only_for_fun_popularity (PEU) } & 82 & 0 & 5 & 2.95 & 1.452 \\ \text { Connect_family_friends (PEU) } & 82 & 0 & 5 & 2.86 & 1.721 \\ \text { Attract_people_events (PU) } & 82 & 0 & 5 & 2.57 & 1.65 \\ \text { Valid N (listwise) } & & & & & \end{array}$

By having images/pictures of brands/products will make potential customer remember better. Research has shown that people remember visual images much easier and better than words (Gutierrez, 2014). This might be the reason of why the highest ranking and mean is 3.78 , which stated that most respondents in this study perceived that the usage of Instagram is much more useful to promote the brands/products. This finding is similar to Thamwika and Lisa (2013) who found that Instagram is not only a great media to promote products/brands, but also to have a good customer relationship, which also answer the finding of the study - i.e. the second mean ranking of 3.67 which is to engage with customers. In addition to the second ranking, Instagram as a strategy and marketing tools has also been perceived as an important usages of Instagram.

From the social aspect, the highest mean is 3:53, where most respondents claim that hashtags (\#) can help facilitate Instagram users find the desired information, such as finding clothes or accessories on the page. In fact, with hashtags, users can locate photographs and family activities or artist in the label. It is so amazed to discover that there are more than 1 million hashtags and posts of the words "Hari Raya" which to lead to the images and videos of Islamic clothing and also veil for the recent festive season.

Similar to other studies and claims, this study also found that among the highly visited Instagram sites are those which displays clothes and accessories, particularly for women. Among the popular Instagram found in this study include some of the Malaysian Instagram sites such as Vivy Yusuf (the Managing director of Fashion Valet), Wak Doyok (co-founder of The Garment) and also Shentell Lee (the Managing Director of Sereni \& Shantel accessory brand). However, to connect family friends and attract people events have been the least perceived used of Instagram (mean $=2,86$ and 2.57). This could be the fact that Instagram is much more in sharing images and videos rather than social networking. 


\section{Al Macrothink \\ Journal of Entrepreneurship and Business Innovation \\ ISSN 2332-8851 \\ 2017, Vol. 4, No. 2}

\subsection{Impact of Instagram}

Table 6 displays a list of possible perceived impacts of Instagram on respondents in this study.

Table 6. Mean Comparison of Impact in the Society $(n=82)$

\begin{tabular}{|c|c|c|c|c|c|}
\hline & $\mathrm{N}$ & Min & Max & Mean & Std. Dev \\
\hline Selfie habits & 82 & 1 & 5 & 4.32 & 0.651 \\
\hline Raise_online_shopping & 82 & 1 & 5 & 4.04 & 0.744 \\
\hline Share_location_good_bad & 82 & 1 & 5 & 4.02 & 0.733 \\
\hline Change_way_industries_communicate & 82 & 1 & 5 & 3.88 & 0.703 \\
\hline Maintain_customer_relationship & 82 & 1 & 5 & 3.83 & 0.714 \\
\hline Powerful_marketing_tools & 82 & 1 & 5 & 3.83 & 0.731 \\
\hline Pictures_use_without permission & 82 & 1 & 5 & 3.78 & 1.075 \\
\hline Change_way_socialize_communicate & 82 & 1 & 5 & 3.73 & 0.728 \\
\hline Way_to_keep_intouch & 82 & 1 & 5 & 3.72 & 0.806 \\
\hline Spent_time_Instagram & 82 & 1 & 5 & 3.56 & 0.865 \\
\hline Engages_relationship_family_and_friends & 82 & 1 & 5 & 3.54 & 0.764 \\
\hline Influences_good_or_bad & 82 & 1 & 5 & 3.47 & 0.823 \\
\hline Everyone_professional_photographer & 82 & 1 & 5 & 3.33 & 0.953 \\
\hline Valid N (listwise) & 82 & & & & \\
\hline
\end{tabular}

Among the highest perceived impact of Instagram is that most respondents state that their selfie habits have increased (mean 4.32). They tend to take pictures of their own (selfie) or with the friends (wefie) and post them on the Instagram. Part of the reasons is that they feel delighted to share their activities with their friends and at the same time to get comments and feedback from the audiences or even "Like". This finding is similar to (2016) study that show people, particularly young adults tends to post all their portraits on their Instagram 
account just for fun and get comments. Although this act is permissible, it has drawbacks as well. Some of the drawbacks include self-craze, a new kind social sickness that is admiration of themselves and their physical appearance (Mehdizadeh, 2010). According Mehdizadeh (2010), the people who post their selfies on different online social networks have a problem of being praised by others. They seek attention and always pose in weird and unnatural styles in their photos for taking the attention of their friends and getting more "Likes" (Mehdizadeh, 2010).

The second highest mean of social impact among the respondents in this study is that Instagram has raised online shopping behavior (mean =4.04). Delizio (2015) in Social Media Examiner website claim that most of Instagram users are shoppers. Unlike Facebook users who report that their primary reason for using that channel is to connect with friends and family, Instagram users may have more of a shopping drive (Deizio, 2015). This could be the reason why online shopping behavior is rank second in the perceived social impact to users.

The third highest mean 4.02 that is Instagram helps to tag and share ones' location. This impact may be good for business but at the same time may be harm depends on who is the audience on the Instagram. Instagram users may locate businesses around them using the geolocation support - enabling them to monitor the location from which an image is recorded and shared at the same time enable customers to locate a business.

\section{Concluding Remarks}

This study shows that there is a huge potential for individual to use Instagram as a socializing hub and business purposes. The study shows that perceived usefulness of the application seems to be a drive factor for the usages of Instagram. Although Instagram can improve the communicative skills, for some people it may control their lives where they tend to spend too much time on it and share private information that should not be posted on to the internet. Since photos and videos are public on Instagram, everyone can view the photos and videos posted on Instagram. This is dangerous as some people may also use it to spy or stalk on others even if they do not know them. Apart from that, the users should be aware of fake followers clogging their Instagram accounts as they might be potential hackers. The privacy terms allow the users to protect their photos and videos from the unknown people or hackers. As these rules keep on changing over time, hence, one should always look at the privacy terms before signing to Instagram. The users must watch out for unreal Instagram followers.

For potential entrepreneurs, there is a huge opportunity for them to consider to use Instagram application as a part of their marketing tools. This is because users of Instagram is increasing. Recent statistic shows that number of active Instagram users is more than 700 million per month and it is not only a popular photo editing and sharing application but also a popular marketing channel for brands, especially in the beauty, fashion, and luxury segment (Statistica, 2017). In fact, Malaysians are the most active Instagrammers in Asia Pacific, according to the latest study by global research firm Kantar TNS (The Star, 2016). Thus, the potential of Instagram to be the hub of marketplace is huge due to rising of the users. 
Although Instagram brings some good values, in marketing perspective, Instagram is certainly not for every company or business. Though Instagram allows photos to be modified, not every photo should be modified as it may detract from the marketing campaign itself. In fact, such advertising of brand or product may actually do more harm than good because it portrays the unrealistic views of the products. Therefore, the marketers should employ Instagram wisely in order to potentially add valuable success to any robust sales and marketing campaign.

Similar to most research, this paper has limitations that point to further opportunities. The author focuses only 82 respondent who have an Instagram account and most of them are either on the author's business contact lists. Building on this research, there are opportunities for further work. The present research could serve as a starting point for more detailed studies. Additional studies on other tertiary institutions should provide further insights into the impact of Instagram on the society, particularly entrepreneurs in Malaysia. This research can be utilised to investigate the use of Instagram not among individual, but also at school, home, workplace, and various other settings, and for a variety of different audiences such as teenagers, young adults, the elderly, or families and should also focus on a bigger sample. For future research, it may be more helpful to examine how an entrepreneurs' psychological state influences motivations for the use of Instagram and also more rigorous methods should be employed to see if this application really have impact among individual, particularly the potential entrepreneurs.

\section{References}

Abbott, W., Donaghey, J., Hare, J., \& Hopkins, P. J. (2014). The perfect storm: The convergence of social, mobile and photo technologies in libraries. VALA 2014. Melbourne, Victoria.

Amedie, J. (2015). The impact of social media on society, advanced writing: pop culture intersections. 2. Retrieved from http://scholarcommons.scu.edu/engl_176/2.

Asehinde, T. (2015). Gain brand recognition: Use Instagram as a social media marketing tool to build and gain brand recognition, Vibe Web Solutions. Retrieved from http://vibewebsolutions.com/build-brand-recognition-use-instagram-as-a-social mediamarketing-tool-to-build-and-gain-brand-recognition/, Accessed on 14 July 2017.

Azjen, I. (1991). The theory of planned behavior. Organizational Behavior and Human Decision Processes, 50, 179-211. https://doi.org/10.1016/0749-5978(91)90020-T

Baškarada, S. (2014). Qualitative study guidelines. The Qualitative Report, 19(40), 1-25.

Boyd, D. M., \& Ellison, N. B. (2007). Social network sites: Definition, history, and scholarship. Journal of Computer-Mediated Communication, 13(1), 210-230. https://doi.org/10.1111/j.1083-6101.2007.00393.x

Cleary, I. (2014). 5 Instagram tools to better manage your marketing, Social Media Examiner, Retrieved from http://www.socialmediaexaminer.com/5-instagram-tools/, Accessed on 20 June 2017. 
Cowden, A. G. (2014, June). Effect of social media marketing on traditional marketing campaigns in young Icelandic companies. Retrieved from http://skemman.is/item/view/1946/18659

Dailymail. (2017). Retrieved from http://www.dailymail.co.uk/sciencetech/article-3688564/Talk-motion -picture-Polaroid-Swing-app-creates-mesmerising-moving-photos-change-scroll.html

Davis, C. H. F., Deil-Amen, R., Rios-Aguilar, C., \& Canche, M. S. G. (2014). Social media, higher education, and community colleges: A research synthesis and implications for the study of two-year institutions. Community College Journal of Research and Practice, 1-14.

Davis, F. D. (1989). Perceived usefulness, perceived ease of use, and user acceptance of information technology. MIS Quarterly, 13(3), 319-340. https://doi.org/10.2307/249008.

Etherington, D. (2013). Instagram reports $90 \mathrm{M}$ monthly active users, $40 \mathrm{M}$ photos per day and 8500 likes per second. Retrieved from https://techcrunch.com/2013/01/17/instagram-reports -90m-monthly-active-users-40m-photos-per-day-and-8500-likes-per-second/

Fischer, E., \& Reuber, R. (2011) Social interaction via new social media: (How) can interactions on Twitter affect effectual thinking and behavior? Journal of Business Venturing, 26(1), 1-18. https://doi.org/10.1016/j.jbusvent.2010.09.002

Gratton, C., \& Jones, S. (2004). Research methods for sports studies. London: Routledge.

Gutierezz, K. (2014). Studies confirm the power of visuals in eLearning. Retrieved from http://info.shiftelearning.com/blog/bid/350326/studies-confirm-the-power-of-visuals-in-elear ning

Harrison, C. (2016). Retrieved from https://www.deakin.edu.au/_data/assets/pdf_file/0008/709892/Harrison-Facebook-and-Surv ey-Monkey-and-research.pdf

Hashim, N. A. (2011). E-commerce and government policy initiatives for Malaysian SMEs: The Need for Assessment, Science and Public Policy, 38(10), 807-816. https://doi.org/10.1093/spp/38.10.807

Hashim, N. A., Mohd Nor, S., \& Janor, H. (2016). Riding the social commerce waves among malaysian entrepreneurs, Geografia: Malaysian Journal of Society and Space, Universiti Kebangsaan Malaysia, 12, 83-94.

Jenkins, L. D. (2015) Instagram marketing: Your complete guide to Instagram success, social media examiner. Retrieved from http://www.socialmediaexaminer.com/instagram-marketing-guide

Kaplan, A. M., \& Haenlein, M. (2010). Users of the world, unite! The challenges and opportunities of social media. Business Horizons, 53(1), 59-68. https://doi.org/10.1016/j.bushor.2009.09.003 
Karahanna, E., Straub, D. W., \& Chervany, N. L. (1999). Information technology adoption across time: A cross sectional comparison of pre-adoption and post-adoption beliefs. MIS Quarterly, 23(2), 183-213. https://doi.org/10.2307/249751

Keenan, A., \& Shiri, A. (2009). Sociability and social interaction on social networking websites. Library Review, 58(6), 438-450. https://doi.org/10.1108/00242530910969794

Kirschner, P. A., \& Karpinski, A. C. (2010). Facebook and academic performance. Computers in Human Behavior, 26, 1237-1245. https://doi.org/10.12691/education-4-13-8.

Kuppuswamy, S., \& Narayan, P. (2010). The impact of social networking websites on the education of youth. International Journal of Virtual Communities and Social Networking (IJVCSN), 2(1), 67-79. https://doi.org/10.4018/jvcsn.2010010105

Leedy, P. D., \& Omrod, J. E. (2005). Practical research: Planning and design (8th ed.). NJ: Prentice Hall.

Mehdizadeh, S. (2010). Self-presentation 2.0: Narcissism and self-esteem on Facebook. Cyberpsychology. Behavior, and Social Networking, 357-364. https://doi.org/10.1089/cyber.2009.0257

Michaelidou, N., Siamagka, N. T., and Christodoulides, G., (2011). Usage, barriers and measurement of social media marketing: An exploratory investigation of small and medium B2B brands. Industrial Marketing Management, 40(7), 1153-1159. https://doi.org/10.1016/j.indmarman.2011.09.009

Moran, M., Seaman, J., \& Tinti-Kane, H. (2011). Teaching, Learning, and Sharing: How Today's Higher Education Faculty Use Social Media, Pearson Learning Solutions and Babson Survey Research Group, Pearson Learning Solutions.

Nagalakshmi, R., \& Treved, M. (2015). Utilization of online survey tools for academic research: A practical approach to survey monkey. The International Journal Research Publication, 4(3), 21- 28.

Ordanini, A. (2006). Information technology and small businesses - antecedents and consequences of technology adoption. Cheltenham: Edward Elgar.

Paquette, H. (2013). Social media as a marketing tool: A literature review. Retrieved from $\mathrm{http} / / /$ digitalcommons.uri.edu/tmd_major_papers/2/

Rogers, E. M. (1995). Diffusion of innovations (4th ed.). New York: Free Press.

Saravanakumar, M., \& Lakshmi, T. S. (2012). Social media marketing. Life Science Journal, 9(4), 4444-4451. Retrieved from http://www.lifesciencesite.com//sj//ife0904/670_13061life0904_4444_4451.pdf

Sekaran, U., \& Bougie, R. (2016). Research methods for business: A skill building approach (7th ed.). John Wiley \& Sons Ltd.

Survey Monkey. (2017). SurveyMonkey How it works. SurveyMonkey. 


\section{Macrothink}

Thamwita, B., \& Backman, L. (2013). Marketing and PR in social media: How the utilization of Instagram builds and maintains customer relationships. Media and Communication, 57-71.

The New York Times. (2012). Facebook buy Instagram for \$1 Billion. Retrieved from https://dealbook.nytimes.com/2012/04/09/facebook-buys-instagram-for-1-billion/

The Star. (2016). The Star Online (29 September 2016), Lee Kah Leng. Retrieved from http://www.thestar.com.my/tech/tech-news/2016/09/29/malaysians-are-the-most-active-insta gram-users-in-apac

Tornatzky, L. G., \& Fleischer, M. (1990). The Process of technological innovation. Lexington Books, Massachusetts.

Valos, M, Polonsky, M. J., Mavondo, F., \& Lipscomb, J. (2014). Senior marketers' insights into the challenges of social media implementation in large organisations: Assessing generic and electronic orientation models as potential solutions. Journal of Marketing Management, 31(7-8). https://doi.org/10.1080/0267257X.2014.977931

Zarrella, D. (2009). The social media marketing book. Retrieved from https://www.researchgate.net/publication/265377226_How_Instagram_can_be_used_as_a_to ol_in_social_networking_marketing

\section{Copyright Disclaimer}

Copyright for this article is retained by the author (s), with first publication rights granted to the journal.

This is an open-access article distributed under the terms and conditions of the Creative Commons Attribution license (http://creativecommons.org/licenses/by/3.0/). 